\title{
IbM KELOMPOK TANI SEJAHTERA YANG MENGHADAPI VIRUS KERITING \\ PADA TANAMAN CABAI RAWIT(Capsicum frutescens $L$.) DI DESA KEDUNG PADANG, REJOSO, NGANJUK
}

\author{
Sri Utami ${ }^{1)}$, Muh. Waskito Ardhi' ${ }^{2)}$, Sigit Ari Prabowo ${ }^{3)}$ \\ ${ }^{1)}$ FPMIPA, IKIP PGRI MADIUN \\ email: sriutami31@yahoo.co.id \\ ${ }^{2)}$ FPMIPA, IKIP PGRI MADIUN \\ email: waskitoardhi@gmail.com \\ ${ }^{3)}$ FIP, IKIP PGRI MADIUN \\ email: sigit27ap@gmail.com
}

\begin{abstract}
Thrips disease in pepper is a complicated issue that is perceived chili farmers in Kedung Padang. The disease is transmitted by Thrips pest sp resulting curly chili plants that do not produce fruit to the fullest. Scarcity and high price of chemical fertilizers made chili farmers find it difficult to get it. In addition, the negative impact of the use of chemical fertilizers to health neglected by farmers chili. The issues above pushed to perform the application of science and technology to society. Objectives and targets are IbM outcomes; (1) raise awareness of the dangers of the use of chemical insecticides; (2) counseling and manufacture of insecticides to control the mahogany seed Plant Pest Organisms (OPT) and; (3) reduce production costs; (4) increase the harvest of chili. The method used in IbM is using extension approaches and manufacture of insecticides from seed Mahogany and direct application on agricultural land area of $1 / 4$ acre pepper plants. IbM carried out for 12 months with activities and work procedures as follows; (1) manufacture of product samples; (2) extension hazards of chemical insecticides and manufacture of insecticides; (3) application of insecticides on 1/4 acre of agricultural land cayenne pepper. IbM been carried out for 11 months ie from January to November 2014. The activities that have been carried out, among others; (1) manufacture of mahogany seed insecticide product samples; (2) insecticide application mahogany seeds $1 / 4$ acres of agricultural land cayenne pepper. Extension hazards of chemical insecticides and insecticide-making mahogany seeds.
\end{abstract}

Keywords: Capsicum frutescens L, insecticides mahoni, prosperous farmer groups.

\section{PENDAHULUAN}

Berdasarkan survei di areal persawahan Desa Kedung Padang, Kecamatan Rejoso Kabupaten Nganjuk diperoleh data bahwa cabai rawit merupakan tanaman favorit para petani desa tersebut. Hal ini disebabkan cabai rawit dapat dipanen beberapa kali dengan harga relative tinggi. Harga cabai rawit sekarang ini mencapai Rp. 30000,- atau lebih, tetapi banyak warga yang tidak dapat menikmatinya karena gagal panen. Tanaman cabai warga kerdil, daunnya keriting, daun dan bungan rontok, serta daun muda berhenti pertumbuhannya. Pada tanaman tersebut ditemukan pula hama sejenis kutu berwarna kuning kecoklatan saat muda dan agak kehitaman setelah dewasa, tubuhnya sangat kecil $\pm 1 \mathrm{~mm}$, sangat lembut bergerombol di dalam bunga atau di permukaan daun bagian bawah. Pada beberapa literatur hama ini disebut Thripssp.
Petani desa Kedung Padang melakukan penyemprotan dengan pestisida sintesis untuk mengendalikan Thrips sp tetapi belum juga teratasi. Hama Thrip sp yang tidak terkendali dan kebiasaan warga yang menggunakan pestisida dengan dosis tinggi melebihi aturan pakai merupakan fenomena yang menunjukkan adanya Resistensi OPT terhadap satu jenis pestisida atau bahkan mungkin resisten terhadap semua jenis pestisida. Oleh karena itu akan lebih baik bila kembali ke alam (back to nature) dengan menggunakan pestisida alami. Pestisida alami mempunyai cara kerja yang berbeda dengan pestisida sintesis dan dapat digunakan untuk mengatasi OPT yang telah kebal terhadap pestisida sintesis. Pestisida alami berasal dari bahan-bahan yang terdapat di alam kemudian diproses menjadi konsentrat dengan tidak mengubah struktur kimianya. Residu pestisida yang alami lebih mudah terurai oleh komponen 
-komponen alam sehingga tidak menyebabkan pencemaran air dan tanah.Daya racun pestisida alami tidak kalah dengan daya racun pestisida sintesis, bersifat selektif, artinya pestisida alami hanya mematikan OPT jenis tertentu, relatif aman terhadap musuh alami OPT, manusia, ikan dan ramah terhadap lingkungan. (Novizan:2002).

Warga desa Kedung Padang akan lebih mudah mendapatkan bahan-bahan pestisida alami karena letak desa yang berada di tepi hutan pegunungan Kendeng. Di dalam hutan tersebut petani dapat memperoleh berbagai macam tanaman yang dapat dimanfaatkan sebagai pestisida botani (Botanical pesticides) seperti pyrethrum, selasih, sirsat, bebedotan, akar wangi/akar rumput teki wangi, mahoni, johar dan lain-lain. Mahoni dan jati merupakan tanaman yang mendominasi hutan pegunungan Kendeng.

Prijono dan Triwidodo (1994) menuliskan bahwa daerah Lebak Banten telah banyak petani menggunakan air rebusan biji mahoni (Swietenia marchophylla) untuk mengusir walang sangit (Leptocorisa oratorius) pada tanaman padi. Ini senada dengan hasil penelitian yang dilakukan oleh Alam(1999) bahwa larutan biji mahoni dengan konsentrasi 3\% sangat efektif untuk mengendalikan kutu daun (Macrosiphoniella sanbroni) pada tanaman krisan. Larutan dibuat dengan cara mencampurkan 3 gr biji mahoni ke dalam $100 \mathrm{ml}$ air, kemudian dihaluskan dengan blender. Larutan ini disaring dan disemprotkan pada daun kirsan yang terserang kutu daun.

\section{METODE PELAKSANAAN PROGRAM}

\section{a. Metode Pendekatan Yang Ditawarkan}

Salah satu cara untuk mengatasi permasalahan yang dihadapi kelompok tani Sejahtera Desa Kedung Padang di atas antara lain dengan kegiatan berikut:

1) Mengadakan penyuluhan kepada petani desa Kedung Padang tentang bahaya insektisida kimia bagi pencemaran tanah dan kesehatan.

2) Pemanfaatan biji mahoni menjadi insektisida botani yang aman dan dapat mengendalikan hama Thrips sp yang menularkan virus keriting pada tanaman cabai rawit.

3) Praktek aplikasi insektisida mahoni pada $1 / 4 \mathrm{H}$ lahan pertanian bersama-sama warga tani.

\section{b. Rencana Kegiatan dan Prosedur Kerja}

1) Pembuatan sampel produk insektisida biji mahoni. Langkah-langkah pembuatan insectisida biji mahoni sebagai berikut:

a) Menggiling/menumbuk halus $0,75 \mathrm{~kg}$ biji mahoni.

b) Mencampur serbuk biji mahoni dengan 2 liter air, kemudian direbus selama 10 menit.

c) Menambahkan 2 sendok makan minyak tanah dan 50 gr deterjen kedalam larutan.

d) Mengaduk hinga terlarut rata dan mendinginkan selama 24 jam.

e) Menyaring larutan di atas.

f) Menambahkan 10 liter air dan diaduk hingga rata.

g) Insektisida biji mahoni siap disemprotkan ke OPT sasaran.

2) Penyuluhan bahaya insektisida kimia dan pembuatan insektisida biji mahoni. Penyuluhan diberikan kepada 50 orang masyarakat desa Kedung Padang yang terdiri dari pengurus desa, pengurus dan anggota kelompok tani Sejatera desa kedung padang. Penyuluhan ini akan menggunakan metode ceramah tentang pentingnya kesehatan, pemutaran vidio pengaruh insectisida bagi kesehatan dan pencemaran lingkungan dan pembuatan insektisida mahoni dengan LCD. Penyuluhan bertempat di halaman Balai Desa Kedung Padang dengan mengundang ketua kelompok tani dari desa tetangga antara lain Desa Jintel, dan Desa Talun.

3) Aplikasi insektisida biji mahoni pada $1 / 4$ hektar lahan pertanian cabai rawit sebagai percontohan. Penyuluhan pada nomor 2 belum cukup dan harus diikuti aplikasi riel ke lapangan karena warga tani tidak akan percaya tanpa ada bukti nyata yang dapat dilihat secara langsung. Langkah-langkah aplikasi sebagai berikut:

a) Sewa lahan pertanian seluas $1 / 4$ hektar milik Ibu Sumiatun anggota kelompok tani sejahtera desa Kedung Padang kecamatan Rejoso-Nganjuk.

b) Pengolahan lahan pertanian, pembuatan bendeng dan saluran air agar siap ditanami cabai rawit.

c) Pembibitan: seleksi benih, perendaman dengan desinfektan, pemerahan, penyemaian ke lahan semai atau polybag kecil/gelas aqua yang telah dilubangi.

d) Pemasangan mulsa plastik pada bedengbedeng yang telah di siapkan sebelum di tanami cabai rawit.

e) Penanaman dan pemeliharaan: pemindahan bibit dari persemian ke lahan tanam, pengairan, penyiangan, pemupukan dengan NPK (15:15:15), hingga panen pertama.

f) Inokulasi hama Thrips sp yang menularkan virus keriting pada tanaman cabai rawit. 
g) Penyemprotan menggunakan insektisida mahoni yang telah disiapkan.

h) Pengamatan dan pencatatan data dan dokumentasi penelitian dari awal hingga akhir secara rinci.

i) Analisis data dan penyusunan laporan pengabdian.

\section{HASILDAN PEMBAHASAN}

a. Kegiatan Pengabdian yang telah dilakukan antara lain:

1) Pembuatan sampel produk insektisida biji mahoni. Langkah-langkah pembuatan insectisida biji mahoni sebagai berikut:

a) Menggiling/menumbuk halus $0,75 \mathrm{~kg}$ biji mahoni.

b) Mencampur serbuk biji mahoni dengan 2 liter air, kemudian direbus selama 10 menit.

c) Menambahkan 2 sendok makan minyak tanah dan 25 gr deterjen kedalam larutan.

d) Mengaduk hinga terlarut rata dan mendinginkan selama 24 jam.

e) Menyaring larutan di atas.

f) Menambahkan 10 liter air dan diaduk hingga rata.

g) Insektisida biji mahoni siap disemprotkan ke OPT sasaran.

Pembuatan sampel produk insektisida mahoni dilaksanakan di laboratorium biologi II Prodi Pendidikan Biologi FPMIPA IKIP PGRI Madiun, dan di rumah Bapak Saidjan desa Kedung Padang Kecamatan Rejoso Nganjuk. Insektisida yang dibuat di laboratorium biologi merupakan campuran antara mahoni, tembakau dan daun jarak. Produk yang dihasilkan sebanyak 15 liter insektisida mahoni dan kemudian dikemas $150 \mathrm{ml}$ dalam botol kaca. Pembuatan sampel insektisida di rumah Bapak Saidjan menghasilkan 2 jenis insektisida mahoni, yaitu Eksbima dan Makoja. Eksbima terbuat dari ekstraks biji mahoni ditambah 2 sendok makan minyak tanah dan satu sendok makan deterjen. Makoja terbuat dari ekstrak biji mahoni, tembakau dan daun jarak. Ini menghasilkan 10 liter makoja dan 5 liter Eksbima. Semua produk diaplikasikan dilahan cabai warga (diberikan kepada petani) dan lahan percontohan IbM pada satu periode penyemprotan. pada pnyemprotan berikutnya dibuat lagi insektisida sejenis secara mendadak dan tidak disimpan lama.

2) Aplikasi insektisida biji mahoni pada $1 / 4$ hektar lahan pertanian cabai rawit sebagai percontohan. Kegiatan yang telah dilakukan sebagai berikut:

a) Sewa lahan pertanian seluas $1 / 4$ hektar milik milik Ibu Sumiatun anggota kelompok tani sejahtera desa Kedung Padang kecamatan Rejoso-Nganjuk.

b) Pengolahan lahan pertanian, pembuatan bendeng dan saluran air agar siap ditanami cabai rawit.

c) Pembibitan: seleksi benih, perendaman dengan desinfektan, pemerahan, penyemaian ke lahan semai.

d) Penanaman dan pemeliharaan: pemindahan bibit dari persemian ke lahan tanam, pengairan, penyiangan, pemupukan dengan NPK (15:15:15), hingga panen pertama.

e) Inokulasi hama Thrips sp yang menularkan virus keriting pada tanaman cabai rawit.

f) Penyemprotan menggunakan insektisida mahoni telah dilakukan 2 kali.

g) Pengamatan dan pencatatan data dan dokumentasi penelitian pada tahap awal.

3) Melanjutkan implementasi insektisida mahoni dan pengamatan serta pendokumentasian bukti riel aplikasi untuk bahan penyuluhan.

4) Membuat modul penyuluhan: modul berjudul Eksbima dan Makoja. Modul disusun sederhana supaya lebih mudah dibaca dan dipahami oleh petani. Modul berisi dua bab yaitu bab satu tentang biopestisida, tinjauan umum, kelebihan dan kelemahan biopestisida. Bab dua berisi macam-macam biopestisida botani, bahan, cara pembuatan dan cara pemakaian. Ada 12 macam biopestisida botani yang diterangkan dalam modul dan semua bahan-bahannya dapat dengan mudah ditemukan disekitar Desa Kedung-Padang Rejoso Nganjuk, sehingga petani mudah mengaplikasikannya.

5) Penyuluhan bahaya insektisida kimia dan pembuatan insektisida biji mahoni. Penyuluhan diberikan kepada 30 orang masyarakat desa Kedung Padang yang terdiri dari pengurus desa, pengurus dan perwakilan anggota kelompok tani Sejatera Desa Kedung Padang. Penyuluhan menggunakan metode ceramah tentang pentingnya kesehatan, pemutaran vidio pengaruh insectisida bagi kesehatan dan pencemaran lingkungan, serta pembuatan insektisida mahoni dengan LCD. Penyuluhan bertempat di Rumah Bapak Saidjan Desa Kedung Padang dengan mengundang ketua kelompok tani dari desa tetangga antara lain 
Desa Jintel, dan Desa Talun. Penyuluhan tidak dilaksanakan di balai desa karena dalam proses renovasi. Peserta antusias terbukti dari banyaknya pertanyaan dan permintaan produk juga minat untuk mempraktekkan pembuatan insektisida mahoni. Warga juga meminta supaya penyuluhan pertanian sering dilakukan, juga untuk permasalahan selain pertanian.

6) Penyusunan laporan akhir pengadian dilakukan secara bersama-sama oleh semua tim abdimas dengan kompak dan pembagian tugas yang jelas.

7) Penyusunan artikel ilmiah untuk diterbitkan pada jurnal Pendidikan IKIP PGRI MADIUN.

8) Pembuatan poster IbM dilakukan salah satu anggota tim dengan masukan dan saran semua anggota tim.

\section{KESIMPULAN}

a. Isektisida botani dari ekstrak biji mahoni dapat digunakan untuk mengendalikan hama Thrips $s p$ yang menularkan virus keriting pada tanaman cabai rawit sebagai solusi mahalnya insektisida kimia.

b. Penyuluhan beserta contoh aplikasi penggunaan insektisida mahoni dan botani yang lain dapat menumbuhkan kesadaran petani akan pengaruh negative insektisida kimia serta meningkatkan kemauan petani dalam pemanfaatan insektisida botani.

c. Insektisida alami dari biji mahoni dapat dibuat dengan cara: $0,75 \mathrm{~kg}$ biji mahoni dikeringkan dan diekstrak, direbus 10 menit dan didinginkan, kemudian ditambah 1 sendok deterjen dan ditambah 2 sendok makan minyak tanah, didiamkan 24 jam, kemudian disaring dengan kain, ditambah 10 liter air, dan siap digunakan.

d. Kegiatan penyuluhan dan praktek di lahan secara bersama-sama dapat meningkatkan kegiatan dan kerjasama antar anggota Kelompok Tani Sejahtera.

\section{REFERENSI}

Arikunto, Suharsimi. (1992). Prosedur penelitian. Jakarta: Rineka Cipta.

Anggoro,Toha. dkk. (2003). Metode Penelitian. Jakarta: Universitas terbuka.

Cahyono, Bambang. (2003). Cabai Rawitteknik budidaya \& Analisis Usaha Tani. Yogyakarta: Kanisius.

Kardinan, Agus. (2004). Tanaman Pengusir dan Pembasmi Nyamuk. Jakarta: Aromedia Pustaka.
Marsono, PL. (2002). Petunjuk Penggunaan Pupuk. Jakarta: Penebar Swadaya.

Martorejo, Toekidjo. (1989). Pengantar Ilmu Penyakit Tumbuhan Bagian dari Perlindungan Tanaman. Yogyakarta: Andi Offset.

Novizan. (2002). Membuat dan Memanfaatkan Pestisida Ramah Lingkungan.Jakarta: Aromedia Pustaka.

Prajnanta, Final. (2007). Mengatasi Permasalahan Bertanam Cabai. Jakarta: Penebar Swadaya.

Rukmana, Rahmat. (2003). Usaha Tani Cabai Hibrida Sistem Mulsa Plastik. Yogyakarta: Kanisius.

Sri Utami. (2005). Pengaruh Perbedaan Komposisi Pupuk NPK Terhadap hasil Panen Cabai Rawit (Capsicum frutescens L). hasil Penelitian. Madiun: IKIP-PGRI MADIUN Press.

\section{GAMBAR KEGIATAN}

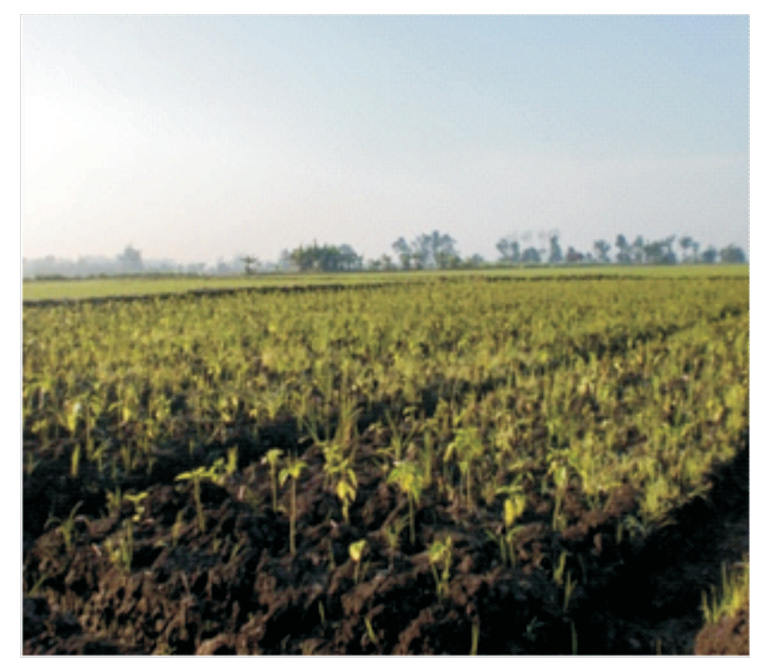

Gambar 1. Tanaman cabai berumur 5 hari setelah di pindah di lahan

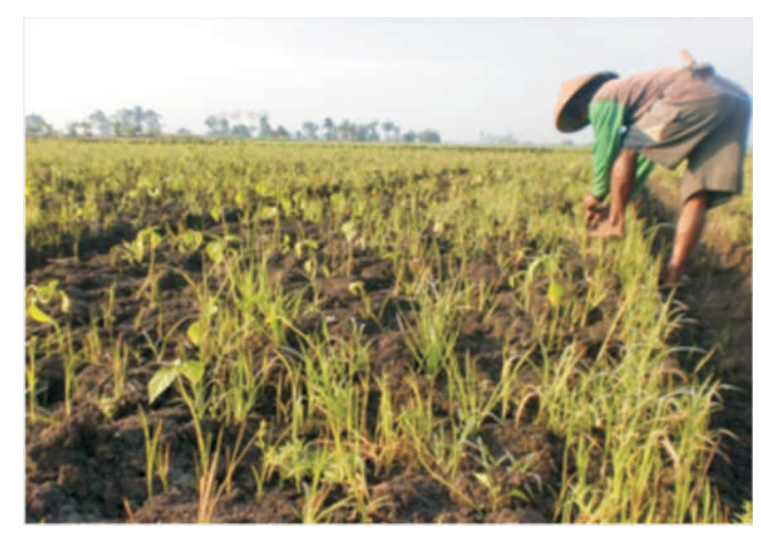

Gambar 2. Tanaman cabai berumur 7 hari dibersihkan dari rumput dan gulma pengganggu lainnya. 


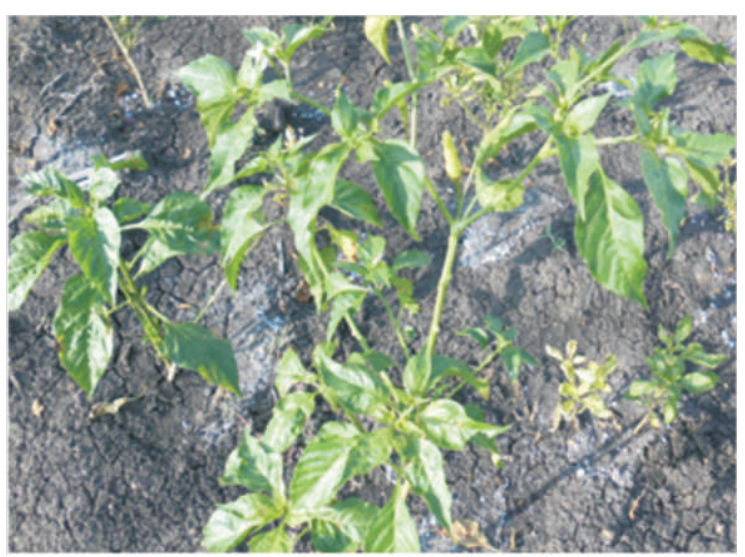

Gambar 3. Cabai berumur 3,5 bulan telah mulai berbuah.

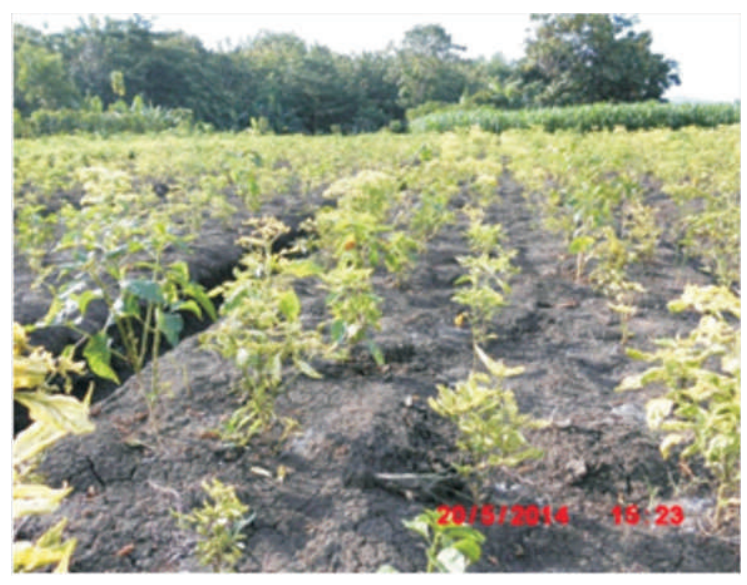

Gambar 4. Penampakan tanaman cabai setelah terserang keriting

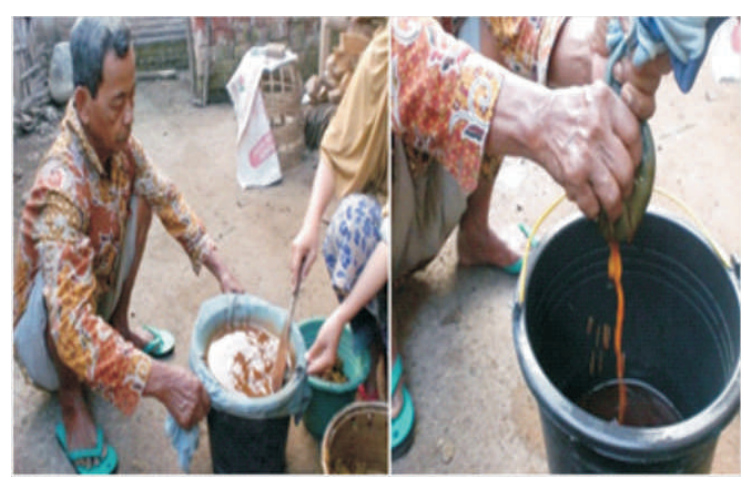

Gambar 5. Penyaringan insektisida mahoni

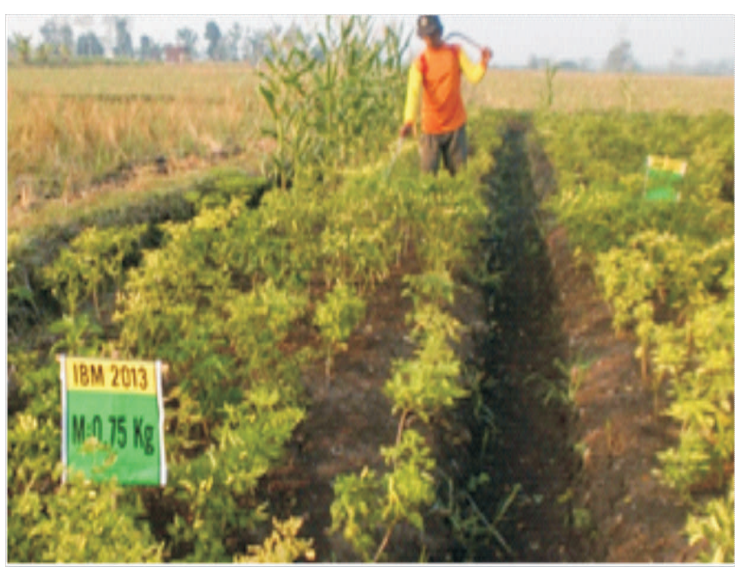

Gambar 6. Penyemprotan dengan insektisida mahoni pada lahan cabai yang terserang keriting.

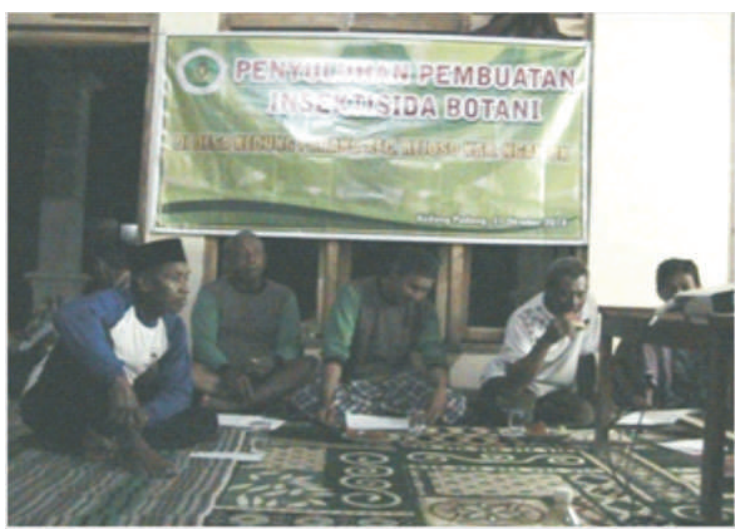

Gambar 7a. Perwakilan Kelompok Tani Sejahtera I dalam Penyuluhan Insektisida Botani.

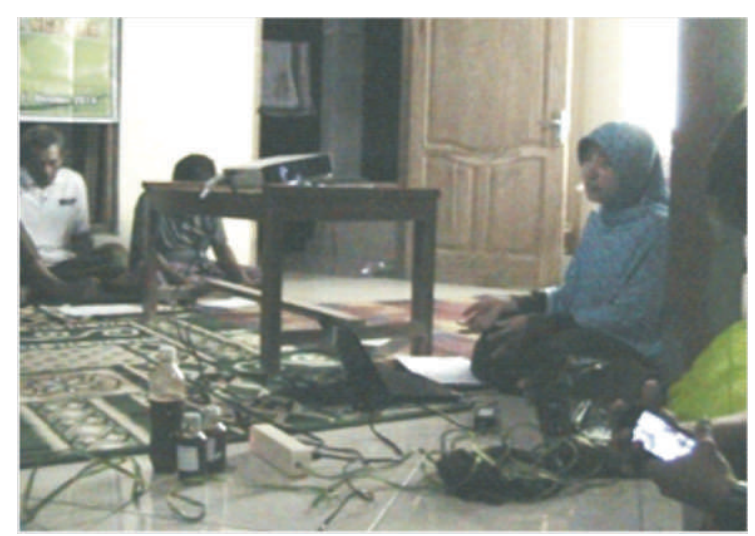

Gambar 7b. Pengabdi sebagai Pembicara Penyuluhan Insektisida Botani 


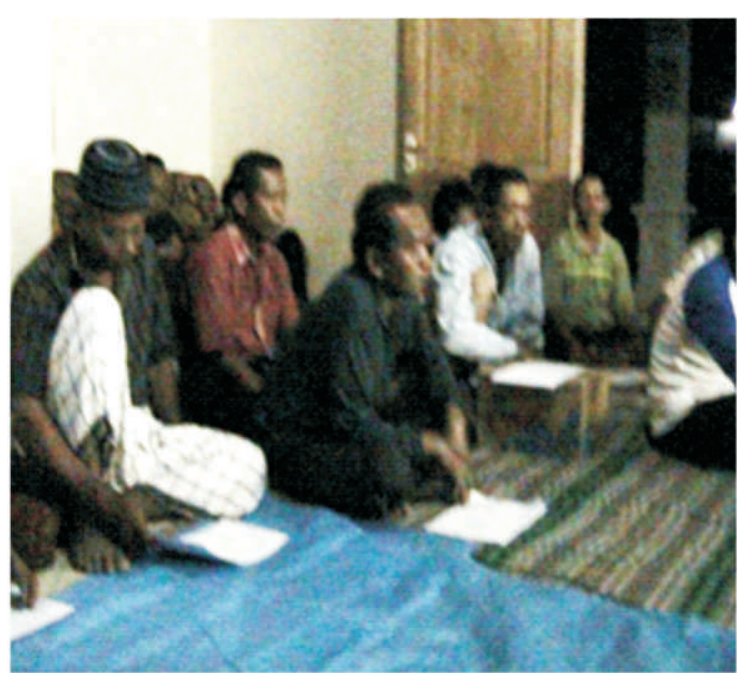

Gambar 7c. Perwakilan Kelompok Tani Sejahtera II dalam Penyuluhan Insektisida Botani.

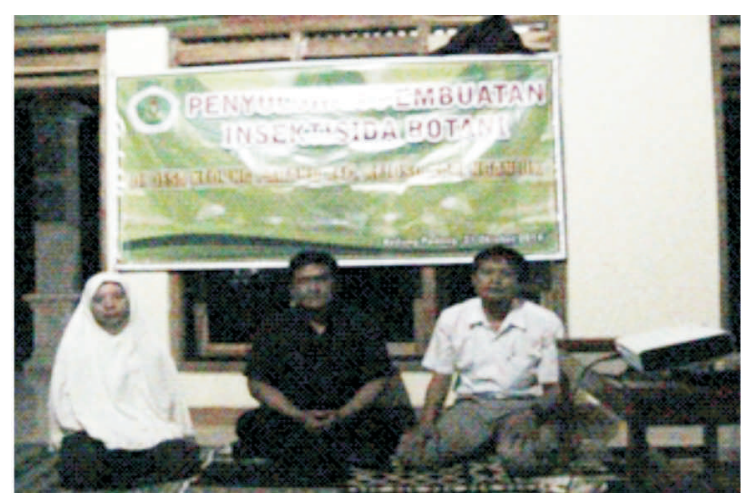

Gambar 8. Tim Pelaksana Abdimas.

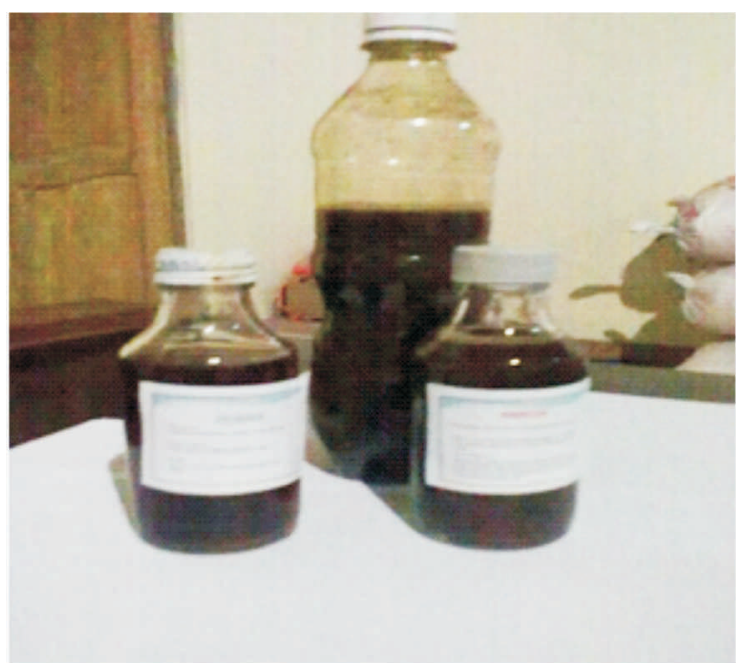

Gambar 9. Contoh Produk Insektisida Eksbima dan Makoja 